\title{
A Dietary Chemical Study of the Protection of Calcium against Cadmium Uptake in Freshwater Fish.
}

\author{
S.Krishnammal ${ }^{1}$, Dr.P.S.Navaraj ${ }^{2}$ \\ ${ }^{1}$ Associate Professor, Dept of Chemistry, EMG Yadava Women's College, Madurai. \\ ${ }^{2}$ Associate Professor, Dept.of Zoology, Yadava College, Madurai.
}

\begin{abstract}
The dietary calcium to reduce the uptake of Cadmium concentration O.mossambicus with emphasis on biochemical and histopathological analysis is projected in this work. The values of $24,48,72$ and $96 h L C_{50}$ of Cadmium to tilapia were 47, 97, 123 and 175 ppm respectively. Therefore, cadmium concentration tested in the sub lethal experiment was $17.5 \mathrm{ppm}$ which corresponds to $10 \%$ of the $96 \mathrm{~h} L C_{50}$. Fish were fed with 0,10 and $50 \mathrm{mg} \mathrm{Ca} \mathrm{Ca}^{2+} \mathrm{g}^{-1}$ food for a month. In the liver, there were blood congestion in sinusoids, vacuolation of hepatocytes and necrosis. In the gills of Cd treatment, edema, lamellar cell hyperplasia, epithelial lifting, lamellar fusion and aneurysm were observed. In the kidney, glomerulus's atrophy, tubular swelling and necrosis were seen. The structural damages may be correlated to the significant increase ( $\leq \leq 0.05)$ in aminotransferase activities. Fish fed with $\mathrm{Ca}^{2+}$ supplemented diets showed a significant alteration when compare with $\mathrm{Cd}$ treatment groups. These results indicated that dietary $\mathrm{Ca}^{2+}$ shall be protective in reducing $\mathrm{Cd}$ uptake and accumulation in fish exposed to environments contaminated with waterborne $\mathrm{Cd}$.
\end{abstract}

\section{Introduction}

Water borne Cadmium $(\mathrm{Cd})$ derives from human activities such as mining and smelting, coal burning, cement manufacturing and use in gasoline, batteries and paint (WHO, 1995) and this is reported in many freshwater species even at the low concentrations $4 \mu \mathrm{g} .1-1$ (Grosell et al., 2006a). Likewise, Cd contamination in surface water and sediment has been observed (Tonmanee, 2001). The effects of waterborne Cd may cause the disruption in $\mathrm{Na}+, \mathrm{Cl}-$ and $\mathrm{Ca} 2+$ regulation, in spinal deformities and in hemoglobin synthesis during acute and chronic exposures (Rogers and Wood, 2004).

Generally, $\mathrm{Ca} 2+$ antagonizes divalent metals such as $\mathrm{Cd}$ and $\mathrm{Zn}$ in water. Calcium reduced $\mathrm{Cd}$ burdens in different tissues of coho salmon (Oncorhynchus kisutch) fed with $8.4 \mathrm{mg} \mathrm{of} \mathrm{CaCl} 2$ and then exposed to 1300 $\mu \mathrm{g} \mathrm{L}-1$ of waterborne Cd for $168 \mathrm{~h}$ (Varanasi and Gmur, 1978). Further, protective action of dietary Ca2+ against the uptake of both waterborne and dietary Cd has been confirmed (Zohouri et al., 2001; Baldisserotto et al., 2005; Franklin et al., 2005; Grosell et al., 2006b), as well as against the uptake of waterborne Zn (Niyogi and Wood, 2006).

In this experiment, the gill and liver tissues have been probed for the $\mathrm{Ca}$ action against $\mathrm{Cd}$. In fish, gills are the first target organs of several xenobiotics because of their wide large interface areas, between external and internal fish environments. Gills are performing important functions such as gas exchange, ion osmoregulation and nitrogen excretion and this structure is particularly sensitive to adverse environmental conditions made by manual or natural (Zohouri et al., 2001). Changes in gill epithelia have been considered good indicators of the effects of xenobiotics on fish (Baldisserotto et al., 2005).

The liver is the site of xenobiotic metabolism in fish. The structural damages in liver metabolism have been supported by the results of biochemical studies that can provide early warning indicators of general as well as specific toxicological responses. Similarly, plasma aminotransferase also treated as the best biological indicator of tissue lesions caused by chemical pollutants (Gingerich, 1982). Lesions that develop in the kidney can expose changes that can occur in different cell types and hence a morphological and physiological study is mandatory (Navaraj, 2005). A detailed understanding about the effects of xenobiotic compounds on biochemical and histopathological analysis, are very important for delineating fish health status and for understanding future ecological hazards (Grosell et al., 2006a).

Oreochromis mossambicus is a commercialized fish marketed in Madurai. A comprehensive information on the effects of heavy metals exposure on fish is available but reports on the antagonistic efficiency of $\mathrm{Ca}$ on $\mathrm{Cd}$ in different tissues of fish is scanty. Hence, this study has been taken to understand the efficiency of the dietary $\mathrm{Ca} 2+$ intake on the uptake of Cadmium in fish, Oreochromis mossambicus. 


\section{Materials And Methods}

This work was carried out at the Department of Chemistry, EMG Yadava Women's College, Madurai during 2009-2011. Water from the college campus was filtered to eliminate chemical contamination. The physicochemical characteristics of water were measured daily as per the standard procedure (APHA, 2005). pH, temperature and Conductivity were measured. A $16 \mathrm{~h}$ light and $8 \mathrm{~h}$ dark photo-period was maintained.

O.mossambicus $12.50 \pm 2.03 \mathrm{~g}$ in body weight and $8.10 \pm 0.51 \mathrm{~cm}$ in total length, were purchased from a local fish market. Fish was acclimatized in laboratory conditions for a week using dechlorinated tap water Fish were fed twice a day with fish commercial feed. Fish was fed with $2.5 \%$ of the initial body weight per day. Cadmium (II) nitrate $\left(\mathrm{Cd}\left(\mathrm{NO}_{3}\right)_{2}\right.$ was directly diluted in water to obtain the desired exposure concentrations.

\section{Diet Preparation}

The commercial diet consists of $\mathbf{3 7 \%}$ crude protein; $14 \%$ crude fat; $3 \%$ crude fiber; $12 \%$ ash and $1 \%$ sodium. This fish food was then ground in a blender, followed by hydration with approximately $40 \% \mathrm{v} / \mathrm{w}$ deionized water.

To prepare the calcium-supplemented diet, the control diet was supplemented with $\mathrm{CaCO}_{3}$ to yield an experimental diet with 10 and $50 \mathrm{mg} \mathrm{Ca}^{2+} \mathrm{g}^{-1}$ dry wt. of food. Calcium carbonate was dissolved in the deionized water and added to the food paste. The resulting paste was mixed and extruded through a pasta maker, air-dried and broken into small pellets by hand. The control diet was prepared by the same method but with the addition of deionized water only.

\section{Acute Toxicity Test:}

The acute toxicity tests were done according to static non-renewal technique (US EPA, 2002). Fish were not fed during the experiment. Preliminary screening was carried out to determine the appropriate concentration range for testing the chemical. The test consisted of a control and at least five concentrations of $\mathrm{Cd}$, three replicates per group, with ten fish in each replicate. At the beginning of the tests and after every $24 \mathrm{~h}$, the number of dead fish was recorded. The results of the median lethality concentration $\left(\operatorname{LC}_{50}\right)$ at $24,48,72$ and $96 \mathrm{~h}$ were computed using the SPSS probit analysis computer program (Finney, 1971) and the Lc50 value was detected.

\section{Sub lethal Toxicity Test Concentration:}

The $96 \mathrm{~h} \mathrm{LC}_{50}$ value of O.mossambicus exposed to $\mathrm{Cd}$ was determined in laboratory as $175 \mathrm{ppm}$

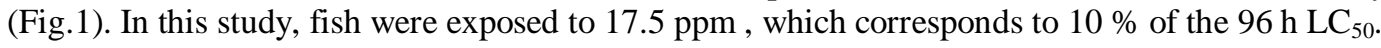

\section{Test Procedure:}

Fish $(n=60)$ were randomly divided into six groups. Each fish group was transferred to each aquarium as follows: group1: normal diet and water (control); group 2: normal diet and waterborne cadmium; group 3: low $\mathrm{Ca}^{2+}$ supplemented diet $\left(10 \mathrm{mg} \mathrm{Ca}{ }^{2+} \mathrm{g}^{-1}\right)$ and normal water; group 4: high $\mathrm{Ca}^{2+}$ supplemented diet $(50 \mathrm{mg}$ $\mathrm{Ca}^{2+} \mathrm{g}^{-1}$ ) and normal water; group 5: low $\mathrm{Ca}^{2+}$ supplemented diet and waterborne cadmium; and group 6: high $\mathrm{Ca}^{2+}$ supplemented diet and waterborne cadmium. All glass flow-through aquaria $\left(50 \times 50 \times 120 \mathrm{~cm}^{3}\right)$ with continuous aeration were filled with 2001 of dechlorinated tap water whose physicochemical characteristics were the same as those described previously. After 30 days treatment, fish from each group were anesthetized with $0.2 \mathrm{~g} .1^{-1}$ MS-222, weighed and measured. The peripheral blood samples were drawn from the caudal vessel and placed in tube containing lithium heparin and then blood was centrifuged at 12,000 g for $5 \mathrm{~min}$. The plasma was then collected and frozen at $-20^{\circ} \mathrm{C}$ until the biochemical study. Following blood withdrawal, the organs (gills, liver and kidney) were removed and prepared for histopathological studies. The relative weight of the organ was expressed as a percentage of the body weight.

\section{Biochemical Studies}

Plasma aminotransferase activities of aspartate and alanine were estimated according to the recommendations of the International Federation of Clinical Chemistry. The reaction mixture contained $\alpha-$ ketoglutarate and AST- and ALT-specific substrates in buffer phosphate. The reaction was started by adding aliquots of the serum in the mixture and was measured photometrically at $505 \mathrm{~nm}$.

\section{Preparation for Light Microscopic Studies}

Small pieces of tissues were fixed in the $10 \%$ buffered formaldehyde for $24 \mathrm{~h}$, dehydrate through a graded series of ethanol and clear with xylene solutions. Following, tissues were embedded in a block using melted paraffin at the embedding station. The paraffin blocks were sectioned at 4-5 $\mu \mathrm{m}$ thickness using a rotary microtome and stained with hematoxylin and eosin. The tissue glass slides were examined for abnormalities (Humason, 1972). 
A Dietary Chemical Study of the Protection of Calcium against Cadmium Uptake in Freshwater Fish.

\section{Semi- quantitative Scoring}

Histopathological alterations were evaluated semi quantitatively by ranking tissue lesion severity. Ranking from - to +++ depending on the degree and extent of the alteration as follows: $(-)$ no pathological alterations; $(+)$ mild; $(++)$ moderate and $(+++)$ severe pathological alterations. This ranking was used by Schwaiger et al. (1997) to establish at an overall assessment value of the histopathological lesion for each individual fish gill. Ten slides were observed from each organ and treatment.

\section{Statistical Analysis}

All data were expressed as Means $\pm \mathrm{SD}$. A two-way analysis of variance was done separately tested in each group. The ANOVA tests were used for the determination of significant differences at $p \leq 0.05$.

\section{Acute Toxicity Tests}

III. Results

From the probit transformed responses curve, O.mossambicus exposed to $24,48,72$ and $96 \mathrm{~h}$ of Cd, theLC $\mathrm{C}_{50}$ values 47, 97, 123 and 175 ppm respectively (Fig. 1) was derived.

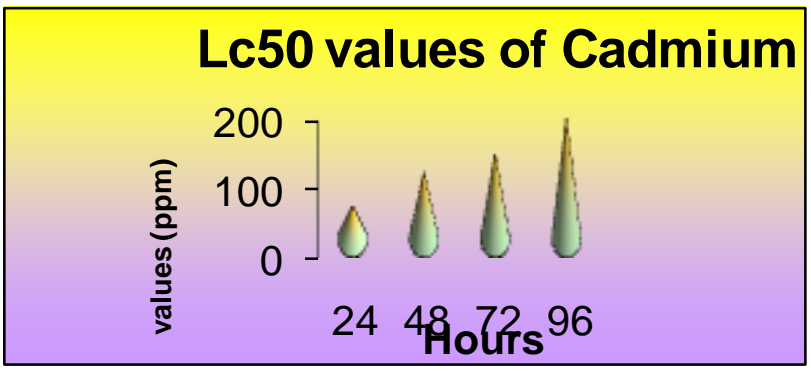

Fig.1. Lc50 values of Cadmium against Oreochromis mossambicus

\section{Biochemical Studies}

Changes in enzyme activity measurements (Mean $\pm \mathrm{SD}, \mathrm{n}=10$ ) in Oreochromis mossambicus exposed to Cadmium are presented in Table 1 and Figs.2\&3. The values of AST and ALT in each group were noted in Table 1. Although Cadmium has a significant increase $(\mathrm{p} \leq 0.05)$ on AST activity but as seen in the figure calcium reduce the effectiveness of Cadmium on these enzymes but it is statistically significant $(p<0.05)$

Table 1. The enzymes activity in fish exposed to Cadmium

\begin{tabular}{|c|c|c|c|c|c|c|}
\hline Enzymes & Group I & Group II & Group III & Group IV & Group V & Group VI \\
\hline AST & 78 & $130^{*}$ & 82 & 65 & $122^{*}$ & $128^{*}$ \\
\hline ALT & 70 & 80 & 76 & 54 & 40 & 77 \\
\hline
\end{tabular}

*Difference was significant at 0.05 level $(\mathbf{p}<0.05)$

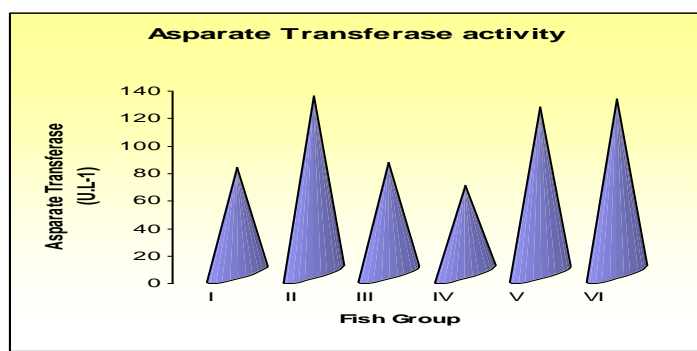

Fig.2. Effect of Cadmium on Asparate Trasferase activity in Oreochromis mossambicus

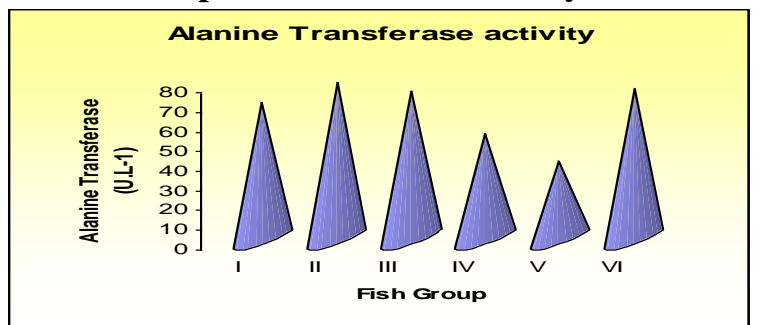

Fig.3. Effect of Cadmium on Alanine Transferase activity in Oreochromis mossambicus Histopathological Studies Gills 


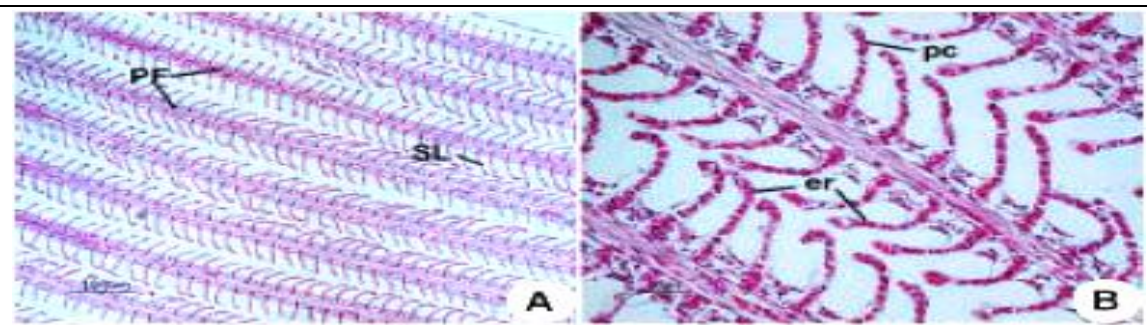

(A) Control ( Group I) showing normal appearance of primary filament (PF) and secondary lamellae (SL). (B) In Group II, High magnification showing erythrocytes (er) within capillary lumen delimited by pillar cells (pc).

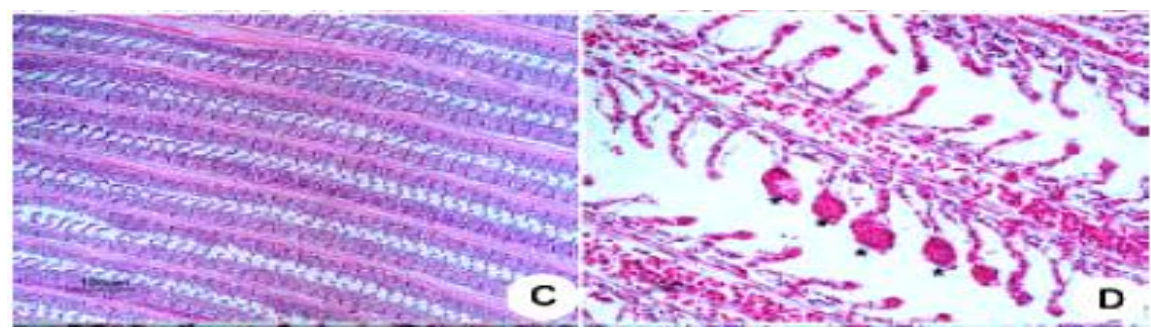

(C) In Group 3, hypertrophy and hyperplasia of secondary lamellar epithelium. (D-E) in group 4 showing severe edema of epithelial cells (arrows) and aneurysm (*).

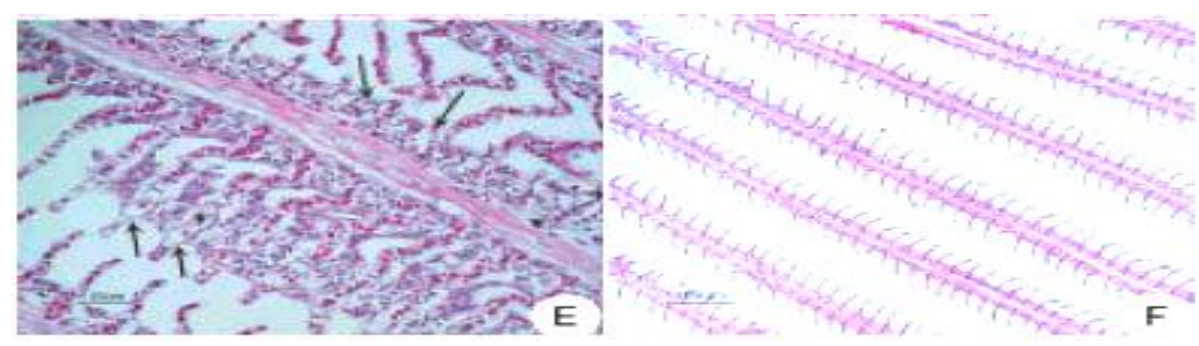

In Group 5 ( E) High magnification showing sever edema of epithelial cells (arrows) and aneurysm (*).(F) In Group 6, gills showed mild hyperplasia of epithelial cells,

\section{Fig.1. Photomicrographs of Gill in Oreochromis mossambicus in each treatment.}

Histological changes observed in the gills of control and $\mathrm{Ca}^{2+}$ supplemented diet in groups 1 and 2 throughout this experiment. Briefly, there were four gill arches on each side of the buccal cavity. Each gill consisted of a primary filament and secondary lamellae. The primary filament had two rows of secondary lamellae that run perpendicular to each filament. The primary lamellar epithelium was one or two cell layers thick. Chloride cells were identified as large epithelial cells with light cytoplasm, usually present at the base of secondary lamellae. Each secondary lamella was made up of two sheets of epithelium delimited by many pillar cells, which were contractile and separated the capillary channels. One to two erythrocytes were usually recognized within each capillary lumen (Figs 2A-B).

In group 2 (Fig.2B), the gills showed severe edema of epithelial cells with some lifting, hypertrophy and hyperplasia of secondary lamellar epithelium (Figs.2C-E). In groups 3,4 and 5, filament cell proliferation was quantified by the height of the filament epithelium. The thickening of the primary lamellar epithelium appeared regular. They showed similar alterations as those observed after $\mathrm{Cd}$ alone treatment but they were less severe in Group 6 (Fig.2F). The semiquantitative scoring of gill lesion is shown in Table 2.

Table 2. Scoring of Gill lesion in O.mossambicus in each group

\begin{tabular}{|c|c|c|c|c|c|}
\hline Group I & Group II & Group III & Group IV & Group V & Group VI \\
\hline- & +++ & + & - & ++ & ++ \\
\hline- & +++ & - & - & + & - \\
\hline- & +++ & + & + & + & ++ \\
\hline
\end{tabular}

Values :(-) none, $(+)$ mild, $(++)$ moderate and $(+++)$ severe occurrence

Kidney 


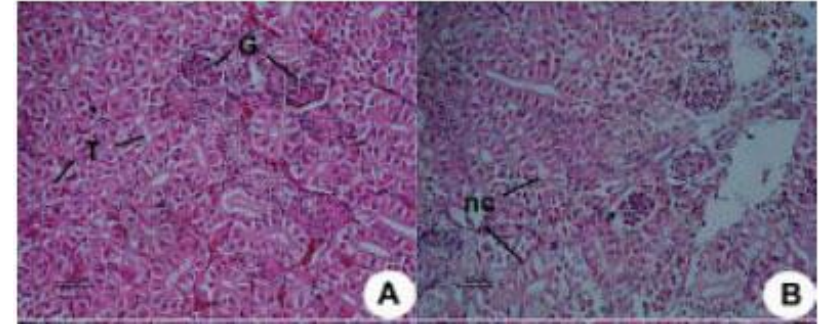

(A) Control group (Group I) showing normal glomerulus (G) proximal tubules (T). (B) Group 2, glomeruli atrophy $(*)$ and tubular necrosis (nc) in some areas

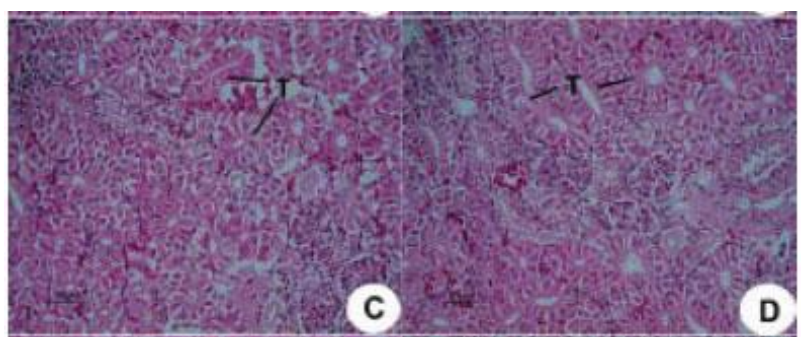

(C-D) Groups 3 and 4, showing normal renal tubules (T) similar to those of the control

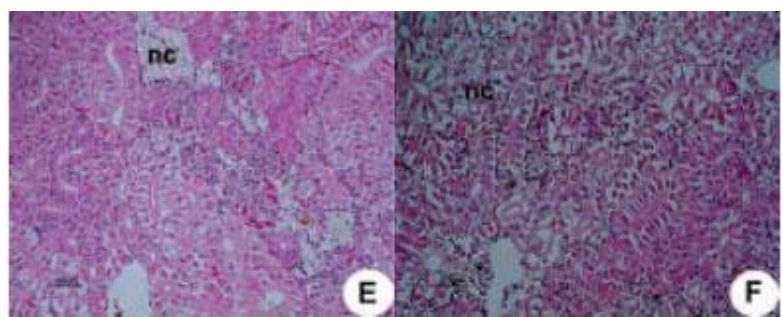

Group $5 \& 6$ - (E-F), tubular necrosis (nc)

Figs.2. Photomicrographs of kidney of Oreochromis mossambicusin each treatment.

In group I, normal structures observed in kidney of control group; numerous renal corpuscles with developed glomeruli and a system of tubules. The proximal tubule composed low columnar epithelial cells with round basal nuclei and brush border (Fig.3A). In group 2, Cd treated group, some glomeruli collapsed or atrophy and tubular necrosis; apoptotic cells and necrosis in some areas (Fig.3B). In groups 3 and 4, fewer changes in the epithelial cells of many tubules, their morphology similar to control (Figs.3C-D). In groups 5 and 6, changes similar to $\mathrm{Cd}$ treated group but they were less severe (Figs. 3E-F). The semiquantitative scoring of kidney lesion is shown in Table 4.

\section{Scoring of Kidney lesion in O.mossambicus in each group}

\begin{tabular}{|c|c|c|c|c|c|}
\hline Group I & Group II & Group III & Group IV & Group V & Group VI \\
\hline- & +++ & + & + & ++ & ++ \\
\hline- & +++ & - & - & + & ++ \\
\hline- & +++ & - & - & + & + \\
\hline
\end{tabular}

Values :(-) none, $(+)$ mild, $(++)$ moderate and $(+++)$ severe occurrence

Liver

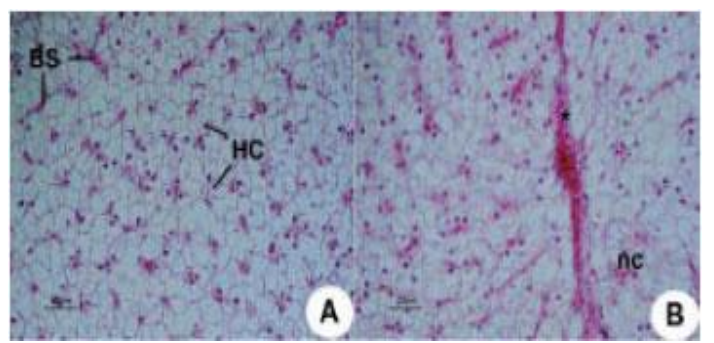

(A) Control group ( Group I) showing normal hepatocytes (HC) and blood sinusoids (BS). (B) Group 2, hepatocytes swelling, sinusoid dilation with blood congestion $(*)$, vacuolation and cell necrosis (nc) were seen. 


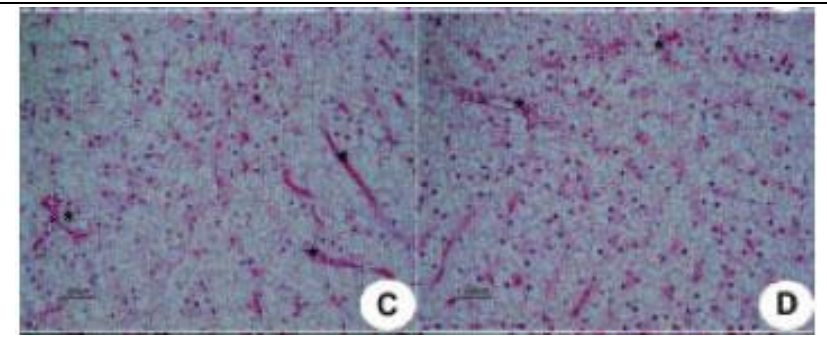

(C-D) Groups 3 and 4, mild congestion $(*)$ and vacuolization were also observed.

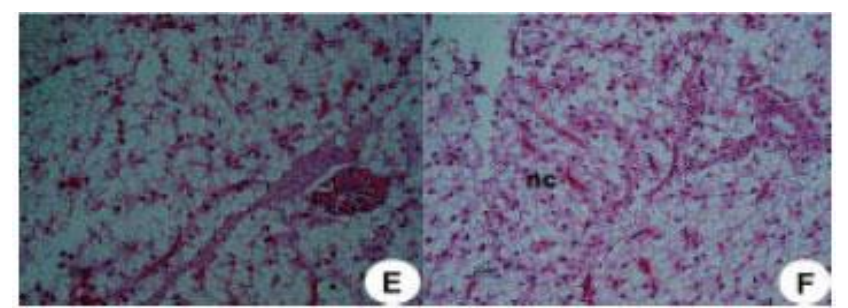

(E-F) Groups 5 and 6, hepatocytes were still swelling and exhibiting necrotic nuclei (nc)

Fig3. Photomicrographs of liver of Oreochromis mossambicus in each treatment.

The micrographs show that liver had parenchyma that contains numerous hepatocytes with interspersed connective tissue containing blood vessels and bile ducts. Vacuolization of hepatocytes resulting from glycogen or fat storage may produce histological variability. Other cell types typically found in liver parenchyma include hematopoietic tissue and macrophage aggregates. The venous blood entered and left liver usually through hepatic portal veins, which collect blood from capillaries known as sinusoids. Bile ducts also occurred within the parenchyma of the liver and form between nearby hepatocytes and bile canaliculi anastomose. Eventually the ducts merged to form the common bile duct (Fig.3A) hepatocytes began to swell and forming edema. The widening of sinusoids may also be observed that were congested with blood. Vacuolization of hepatocytes was visible along with pyknotic nuclei in many areas (Fig.3B). Hepatocytes began to swell and there was edema and presence of macrophages. The widening of sinusoids may also be observed that were congested with blood. Vacuolization of hepatocytes was visible along with pyknotic nuclei in many areas (Figs.3C-3F).

Scoring of Liver lesion in O.mossambicus in each group

\begin{tabular}{|c|c|c|c|c|c|}
\hline Group I & Group II & Group III & Group IV & Group V & Group VI \\
\hline- & +++ & + & + & ++ & ++ \\
\hline- & +++ & + & + & + & ++ \\
\hline- & +++ & - & + & + & ++ \\
\hline- & +++ & + & - & + & + \\
\hline
\end{tabular}

Values :(-) none, $(+)$ mild, $(++)$ moderate and $(+++)$ severe occurrence

\section{Discussion}

Histopathological alteration on gill epithelial in several previous studies have been described similarly in this study i.e., gill cells degeneration, uplifting of epithelial, necrosis, lesions and inflammatory infiltration. The first sign of lesions included edema of epithelial cells observed in the present study. Similarly, the secondary lamellae showed capillary congestion or aneurism in this work agrees to those reported in Puntius altus exposed to Cadmium (Jiraungkoorskul et al., 2006) and Poronotus triacanthus exposed to copper (Jiraungkoorskul et al., 2007). The lamellar aneurism resulted from the collapse of the pillar cell system and the breakdown of vascular integrity with a release of large quantities of blood that push the lamellar epithelium outward. Otherwise, thickening of the primary lamellar epithelium, hypertrophy and hyperplasia of epithelial, chloride cells, lifting and fusion of secondary lamellae were also observed. The distal extremities of secondary lamellae were bent, with a reduction of the interlamellar space. Several studies pointed out that chloride cell hyperplasia occurred in response to the need to eject the toxicant absorbed by the gills (Gill et al., 1988; Marshall and Grosell, 2005).

The alterations occurred in the kidney in this study were dilation of Bowman's space, glomeruli atrophy and tubular swelling. The degeneration and necrosis of tubular epithelial cells of the first proximal tubule were also observed. Because the excretion of divalent ions is a major function of the renal tubular epithelium, pollution with heavy metals should be highly likely to affect these cells (Gingerich, 1982). 
In fish liver is both a storage organ as well as the detoxification centre (Olsson et al., 1996). The histopathological alterations in the liver observed in the present study were sinusoid dilation with blood congestion, vacuolation, hemosiderin accumulation and cell necrosis. The vacuolation of hepatocytes may indicate an imbalance between the rate of synthesis of substances in the parenchymal cells and the rate of their release into the systemic circulation (Gingerich, 1982). Toxic of $\mathrm{Cd}$ can result in the injured cells dying by necrosis. The structural damages may be correlated to the significant increase $(\mathrm{p} \leq 0.05)$ in AST and ALT activities. Low levels of these enzyme activities are usually found in the blood. There shall be an additional release of these enzymes in the bloodstream if any damage in the body.

Previous studies have found significant reductions in whole body $\mathrm{Cd}$ uptake from the water and diet when rainbow trout were fed a diet supplemented with $60 \mathrm{mg} \mathrm{CaCO}_{3} \mathrm{~g}^{-1}$ (Baldisserotto et al., 2004b, 2005; Franklin et al., 2005), or $60 \mathrm{mg} \mathrm{CaCl} 2$ (Zohouri et al., 2001; Baldisserotto et al., 2004a). Freshwater fish have two primary uptake pathways for essential ions i.e., $\mathrm{Ca}^{2+}, \mathrm{Na}^{+}$, the gills as waterborne ions and the gastrointestinal tract as dietary ions. Fish can regulate the total uptake depending on the environmental situations. For example, tilapia (O. mossambicus) up-regulate intestinal $\mathrm{Ca}^{2+}$ uptake when living in water with low $\mathrm{Ca}^{2+}$ concentration (Flik et al., 1995). Therefore, if the fish can acquire more ions via the gastrointestinal route, fish can decrease branchial ion uptake rates and thereby subsequently reduce the uptake of metals sharing the common branchial pathway. For example, $\mathrm{Cd}^{2+}, \mathrm{Zn}^{2+}$ shares the same transport pathway with $\mathrm{Ca}^{2+}($ Verbost et al., 1989; Niyogi and Wood, 2004) and previous studies have shown that dietary $\mathrm{Ca}^{2+}$ supplementation decreased waterborne $\mathrm{Ca}^{2+}$ uptake and subsequently waterborne $\mathrm{Cd}^{2+}$ uptake (Zohouri et al., 2001; Baldisserotto et al., 2004ab, 2005). No data is available regarding $\mathrm{Ca}_{2}^{+}$concentrations in the natural diet of fish, but $\mathrm{Ca}^{2+}$ is available in abundance in crustacean exoskeleton and mollusk shells. Interestingly though, Sherwood et al. (2000) reported that wild yellow perch (Perca flavescens) treated in heavy metals tend to eat relatively more invertebrates than fish.

In conclusion, the results presented in this study show that the efficacy of dietary calcium supplementation in reducing biochemical and histopathological alterations associated with sublethal exposed to waterborne Cadmium uptake in fish.

\section{Acknowledgements}

The authors sincerely register their gratitude and thanks to University Grants Commission, New Delhi for providing financial support under minor research project to carry out this work. The authors also thank the management and principal of EMG Yadava Women's College, Madurai for their whole hearted support in successful completion of this project.

\section{References:}

[1] Association (APHA), 2005. Standard Methods for the Examination of Water and Wastewater. 21st Edn., The American Public Health Association, American Water Works Association and Water Pollution Control Federation, Washington,DC. Baldisserotto, B., C. Kamunde, A. Matsuo and C.M. Wood, 2004. A protective effect of dietary calcium against acute waterborne cadmium uptake in rainbow trout. Aquat. Toxicol., 67: 57-73.

[2] Kamunde, A. Matsuo and C.M. Wood, 2004. Acute waterborne cadmium uptake in rainbow trout is reduced by dietary calcium carbonate. Comp. Biochem. Physiol., 137C: 363-372

[3] Chowdhury and C.M. Wood, 2005. Effects of dietary calcium and cadmium on cadmium accumulation, calcium and cadmium uptake from the water and their interactions in juvenile rainbow trout. Aquat. Toxicol., 72: 99-117

[4] Horder, 1986. International federation of clinical chemistry (IFCC) methods for the measurement of catalytic concentration of enzymes. Part 1 IFCC method for alanine aminotransferase (L-alanine: 2-oxoglutarate aminotranferase, EC 2.6.1.2). J. Clin. Chem. Clin. Biochem., 24:342-349.

[5] Horder, R. Rej, 1986. International federation of clinical chemistry (IFCC) methods for the measurement of catalytic concentration of enzymes. Part 3. IFCC method for aspartate aminotransferase (L-aspartate: 2-oxoglutarate aminotranferase, EC 2.6.1.1). J. Clin. Chem. Clin.Biochem., 24: 497-510.

[6] Probit Analysis. 3rd Edn., Cambridge University Press, Cambridge, UK., pp: 76-80.

[7] Flik, G., P.M. Verbost and S.E. Wendelaar-Bonga, 1995. Calcium Transport Processes in Fishes. In: Fish Physiology Cellular and Molecular Ionic Regulation, Wood, C.M. and T.J. Shuttleworth (Eds.). Vol. 14. Academic Press, San Diego, pp: 317-341. Franklin, N.M., C.N. Glover, J.A. Nicol and C.M. Wood, 2005.

[8] Calcium/cadmium interactions at uptake surfaces in rainbow trout: Waterborne vs dietary routes of exposure. Environ. Toxicol. Chem., 24: 2954-2964

[9] Pant and H. Tewari, 1988. Branchial pathogenesis in a freshwater fish, Puntius conchonius Ham., chronically exposed to sublethal concentrations of cadmium. Ecotoxicol. Environ. Safe, 15: Gingerich, W.H., 1982. Hepatic Toxicology of Fishes. In: Aquatic Toxicology, Weber, L.J. (Ed.). Raven Press, New York, pp: 55105 .

Grosell, M., R.M. Gerdes and K.V. Brix, 2006. Influence of Ca, humic acid and pH on Cadmiumaccumulation and toxicity in the fathead minnow during prolonged water-borne Cadmiumexposure. Comp. Biochem. Physiol., 143C: 473

[10] Geredes and K.V. Brix, 2006. Chronic toxicity of Cadmiumto three freshwater invertebrates. Environ. Toxicol. Chem., 25: 97-104

[11] Animal Tissue Techniques. 3rd Edn., W.H. Freeman and Co., San Francisco, ISBN: 9780716706922. Jiraungkoorskul, W., E.S. Upatham, M. Kruatrachue, S. Sahaphong, S. Vichasri-Grams and P. Pokethitiyook, 2002. Histopathological effects of roundup, a glyphosate herbicide, to Tilapia (Oreochromis mossambicus). ScienceAsia, 28: 121-127.

[12] Sahaphong and K. Niwat, 2007. Toxicity of copper in butterfish (Poronotus triacanthus): Tissues accumulation and Ultrastructural changes. Environ. Toxicol., 22: 92-100. 


\section{A Dietary Chemical Study of the Protection of Calcium against Cadmium Uptake in Freshwater Fish.}

[13] Sahaphong, K. Niwat and K. Myung-Huk, 2006. Histopatholo gical study: The effect of ascorbic acid on cadmium exposure in fish (Puntius altus). J. Fisher. Aquat. Sci., 1: 191-199.

[14] Grosell, 2005. Ion Transport, Osmoregulation and Acid-base Balance. In: Physiology of Fishes, Evans, D. and J.B. Claiborne, (Eds.). 3rd Edn., $\quad$ CRC, Boca Raton, FL., USA., pp: 177-230. Niyogi, S. and C.M. Wood, 2004. Kinetic analyses of waterborne $\mathrm{Ca}$ and $\mathrm{Cd}$ transport and their interactions in the gills of rainbow trout (Oncorhynchus mykiss) and yellow perch (Perca flavescens), two species differing greatly in acute waterborne Cd sensitivity. J. Comp. Physiol., 174B: 243-253

[15] Haux, 1996. Influence of seasonal changes in water temperature on cadmium inducibility of hepatic and renal metallothionein in rainbow trout. Mar. Environ. Res., 42: 41-44.

[16] Sherwood, G.D., J.B. Rasmussen, D.J. Rowan, J. Brodeur and A. Montela, 2000. Bioenergetic cost of heavy metal exposure in yellow perch (Perca flavescens): In situ estimates with a radiotracer technique. Can. J. Fish. Aquat.Sci.,57:441-450. Tonmanee, N., 2001. Cadmiumcontamination in Klity Creek, Klity Village, Kanjanaburi Province, Thailand. Int. Water Assoc. Specialist Group Diffuse Pollut., 15: 1-12.

[17] US Environmental Protection Agent, 2002. Methods for measuring the acute toxicity of effluents and receiving waterstofreshwaterandmarineorganisms.5thEdn.,EPA821R02012.

Varanasi, U. and D.J. Gmur, 1978. Influence of water-borne and dietary calcium on the uptake and retention of Cadmiumby coho salmon (Oncorhynchus kisutch). Toxicol. Applied Pharmacol., 46: 65-75.

[18] Verbost, P.M., J. Van-Rooij, G. Flik, R.A.C. Lock and B.S.E. Wendelaar, 1989. The movement of cadmium through freshwater trout branchial epithelium and its interference with calcium transport. J. Exp. Biol., 145: 185-197.

[19] WHO, 1995. Environmental Health Criteria No. 165, Lead, inorganic. International Programme on Chemical Safety(IPCS),WorldHealthOrganisation,Geneva.

Zohouri, M.A., G.G. Pyle and C.M. Wood, 2001. Dietary $\mathrm{Ca}^{2+}$ inhibits waterborne $\mathrm{Cd}$ uptake in Cd-exposed rainbow trout, Oncorhynchus mykiss. Comp. Biochem. Physiol., 130C: 347-356. 